\title{
Teaching the Academic Subject Area of Medical and Pharmaceutical Merchandising to ProspectiveGraduate Nurses using the Instruments of Distance Learning
}

\author{
Yastremska SO, Ravliv Yu A* and Groshovyi TA
}

Department of Pharmacy management \& pharmaceutical science, State Institution of Higher Education "Ivan Horbachevsky Ternopil State Medical University of the Minisrty of Health", Ukraine, Europe

\section{Article Info}

\section{*Corresponding author:}

Ravliv Yu A

Department of Pharmacy management \& pharmaceutical science

SHEI "Ternopil State Medical University of the $\mathrm{MH}$ of Ukraine

Ukraine, Europe

Tel: +38 0977205632

Email: ravlivuylia@ukr.net

Received: August 8, 2018

Accepted: October 15, 2018

Published: October 23, 2018

Citation: Yastremska SO, Ravliv YA, Groshovyi TA. Teaching the Academic Subject Area of Medical and Pharmaceutical Merchandising to Prospective Graduate Nurses using the Instruments of Distance Learning. Madridge J Nov Drug Res. 2018; 2(1): 90-93.

doi: 10.18689/mjndr-1000113

Copyright: @ 2018 The Author(s). This work is licensed under a Creative Commons Attribution 4.0 International License, which permits unrestricted use, distribution, and reproduction in any medium, provided the original work is properly cited.

Published by Madridge Publishers

\begin{abstract}
This work presents using the instruments of distance learning in student training at the Research and Training Institute of Nursing of Ivan Horbachevsky Ternopil State Medical University in the academic subject area of Medical and Pharmaceutical Merchandising. As students not only learn their text-based subject material in a distance mode, but also view video lectures at their convenient time, this allows for improving the level of theoretical training of specialists with higher nursing education and also for reinforcing their knowledge base required to improve practical skills. However, the students' training needs further comprehensive upgrades and additions.
\end{abstract}

Keywords: Instruments of distance learning; Medical and pharmaceutical merchandising; Higher nursing education; Professional training; Electronic informational education environment.

\section{Introduction}

\section{Problem statement}

The analysis of the making of theoretical and methodological premises of nursing education in the second half of the 19th century and in the beginning of the 20th century has shown that a characteristic feature of this period was the development of a scientific concept of phased nursing education, with the United States of America becoming the main centre of its development [1]. The American model of phased higher nursing education, which was predominant worldwide until the end of World War II, included the following: training of nursing administrators for nursing services, introduction of fundamental and postgraduate university-based nursing education, introduction of Master's programs and training of Masters of Science in Nursing (in 1920) [2].

Almost simultaneously, the principal premises of fundamental nursing training begin to emerge in Europe (the middle of the 20th century). Thus, the European Agreement on the Instruction and Education of Nurses was signed by several European countries (Denmark, Greece, United Kingdom, France, and West Germany) in 1967 [3].

It should be noted that in the late 80 s and early 90 s of the last century the issues of nursing education have remained in the focus of Ukrainian scholars, who discussed these issues at international, national and regional meetings and seminars. A groundbreaking change in Ukrainian system of professional education of nursing professionals occurred in 1992 via reforming of healthcare in accordance to international experience and standards, which, at the same time, called for the implementation of a 
phased system of nursing education. It is then that active identification of novel trends for development of Nursing and nursing education began in Ukraine $[3,4]$. The researchers have provided scientific substantiation and developed methodological approaches to reforms of nursing education in the independent nation of Ukraine [5] and the first schools and colleges of Nursing were created, whose purpose was to provide an enhanced level of nursing training. In the same year, the first Faculties/Departments of higher professional education in Nursing were opened, which have met the challenge of consecutive improvement of professional and educational levels of nursing professionals [6]. Already in 1994, professional education aggregates begin to emerge within the system of professional nursing education, modelled after the sequence of 'high school - nursing school/college institution of higher learning'.

Dr. Patricia Benner, a Professor of Nursing at the School of Nursing of the University of California, San Francisco, provides her extensive recommendations on education and training of nurses. According to Prof. Benner, the education must aim at attaining higher levels and personnel training must occur through an improved system of education, which facilitates a continuous academic progression. In part, she points out that by the year 2020 the proportion of nurses with a Bachelor degree will reach $80 \%$ [7].

The coming of higher nursing education into being was investigated by a number of Ukrainian scholars, including Palasyuk, Shehedyn and others $[8,9]$.

The review of recent literature sources and publications demonstrates a rapid development of scientific and methodological premises of distance learning in recent decades. Distance learning is a model of education where the educational process uses the best innovative instruments and models oflearning based oncomputerand telecommunications technology [10].

As of today, distance learning is seen as a novel universal humanistic educational model based on information and telecommunication technology, paving the way to liberalisation, humanisation and variability of education by allowing the students to use the entire bulk of their learning material and promoting self-education with simultaneous availability of consultations and follow-up by the teaching staff [11].

At the present time, the distance-based education model has a number of serious advantages over other models due to its accessibility and high information gain. The concept of lifelong learning is natural to many trades and vocations; however, it is especially important for nurses. Understanding the complexity of continuous changes in Nursing and perceiving nursing as an independent and unique professional area helps many nurses to be acutely aware of the importance of lifelong training. The essence of such training is making the person open to new ideas, solutions, skills or behavioural models at any age [12].

After evaluation of the European and American experience of distance-based education and with support from the
Ministry of Health of Ukraine, Ivan Horbachevsky Ternopil State Medical University has launched a distance education centre of nursing training [11].

\section{The Aim of the Work}

It was to provide substantiation and experimental verification for the improved methodology of teaching Medical and Pharmaceutical Merchandising using the instruments of distance learning in future nurses with higher education.

\section{Presentation of main study material}

In Ukraine, training of Bachelors and Masters of Science in Nursing with instruments of distance learning is performed at the Research and Training Institute (RTI) of Nursing of Ivan Horbachevsky Ternopil State Medical University (TSMU), at Zhytomyr Institute of Nursing and at Lviv Institute of Nursing.

Distance learning at the RTI of Nursing of TSMU is one of the available training modalities based on an aggregate of educational methods and administration of educational procedures to maintain distance-based education using modern information and telecommunication systems and didactic instruments [13].

The Department of Pharmacy Management, Economics, and Technology of Ivan Horbachevsky Ternopil State Medical University of the MoH of Ukraine (a State Institution of Higher Learning) teaches the subject area of Medical and Pharmaceutical Merchandising to nursing students of the first (Baccalaureate) and the second (Master's) levels of distancebased higher education. However, the names of the topics in this subject's curriculum for Master's Program resemble those in the Baccalaureate curriculum, which calls for improvement of this subject's curriculum for Master's Program by appending it with the elements dedicated to management and marketing. Our suggestion is to give the subject area for prospective Masters of Science in nursing the following name: 'Marketing of Medical and Pharmaceutical Merchandise'. During their studies of the improved subject area, the students will investigate and perform marketing assessment of medical devices market. Therefore, the objective of faculty members is to develop a new curriculum in this subject area and to provide adequate information and didactic maintenance for the new course.

A detailed analysis of the instruction hours assigned for lectures, practical classes and independent work of students (as summarized in table 1) proves that prospective Masters of Science in Nursing need more hours in this subject area.

Table1. The distribution of instruction hours in Medical and Pharmaceutical Merchandising

\begin{tabular}{|c|c|c|c|c|c|}
\hline \multirow[b]{2}{*}{ No. } & \multirow{2}{*}{$\begin{array}{l}\text { Levels of higher } \\
\text { education }\end{array}$} & \multicolumn{4}{|c|}{ Number of hours acc. to curriculum } \\
\hline & & $\begin{array}{l}\text { Total } \\
\text { hours }\end{array}$ & $\begin{array}{c}\text { Hours of } \\
\text { practical classes }\end{array}$ & $\begin{array}{l}\text { Hours of } \\
\text { lectures }\end{array}$ & $\begin{array}{c}\text { Hours of } \\
\text { independent work }\end{array}$ \\
\hline 1. & $\begin{array}{c}\text { Level } 1 \text { (BSN) } \\
\text { (2 years of study) }\end{array}$ & 90 & 24 & 16 & 56 \\
\hline 2. & $\begin{array}{c}\text { Level } 1 \text { (BSN) } \\
\text { (1 year of study) }\end{array}$ & 90 & 18 & 16 & 50 \\
\hline 3. & $\begin{array}{c}\text { Level } 2 \text { (MSN) } \\
\text { (2 years of study) }\end{array}$ & 90 & 18 & 16 & 76 \\
\hline
\end{tabular}


The sufficiently high levels of theoretical and practical training of students in the Master's program allow for a distancebased mode of instruction in Medical and Pharmaceutical Merchandising. Using the distance-based learning has a number of advantages over traditional tuition; in part, it allows increasing the qualification levels of the nurses who combine work and study and offering educational programs to foreign nationals $[14,15]$.

In order to provide distance-learning students with study materials meeting the program of professional education of prospective Masters of Science in Nursing, an electronic informational education environment has been drafted, developed and implemented. As a core structure, this environment uses an LMS MOODLE-based Web portal of electronic tuition of the RTI of Nursing of TSMU (at http://dl.tdmu.edu.uA) with access to all digital and multimedia content used in distance learning. This content includes video and audio courses available in different languages (English, Russian and Ukrainian), video tutorials in various subject areas, a nursing media library, resource materials in various aspects of learning, information and reference materials and interactive testing systems for self-assessment and evaluation of knowledge.

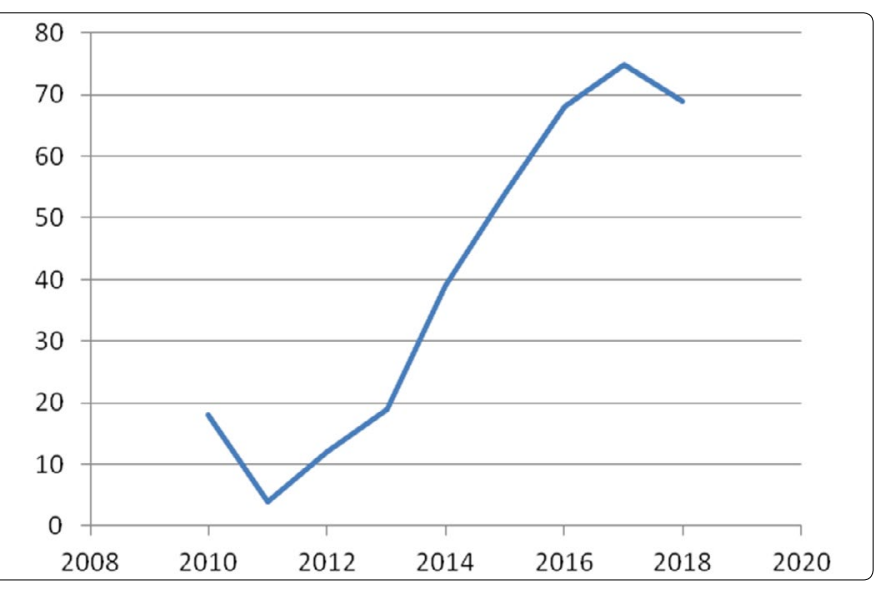

Figure 1. Changes of the student population with time at the MSC level of the RTI of Nursing.

Distance learning is becoming increasingly popular with practicing nurses. The Master's training program started with 18 persons in 2010 (Figure 1), while by 2017 the quantity of students studying for their Master's degree has increased 4 times. Thus, the students have become more interested not only in the option of distance learning (DL), but also in the subjects included in the curriculum.

A pedagogical experiment was carried out in order to check the performance of the system developed for teaching the subject area of Medical and Pharmaceutical Merchandising to prospective Masters of Science in Nursing using DL instruments.

Test groups (TG) enrolled the students on distance learning (53 students). These academic groups were formed at the RTI of Nursing during the first-semester tuition in the subject area of Medical and Pharmaceutical Merchandising in years 20162017. The students in the control groups (CG) studied the same subject area in a setting of traditional tuition paradigm at Zhytomyr Institute of Nursing and at Lviv Institute of Nursing.
Thus, CGs included 53 subjects and TGs included 45 subjects. Therefore, this experimental study enrolled 98 prospective Masters of Science in Nursing with almost identical qualitative and quantitative characteristics.

For the purposes of analysis of results of the experimental research, we have compared the numerical indicators of baseline and the final maturity of components defining the readiness of prospective Masters of Science in Nursing in $\mathrm{CGs} / \mathrm{TGs}$ to their professional meta-activity.

The resulting numerical indicators of readiness of prospective Masters of Science in Nursing to their professional activity (in course of distance learning in the subject area of Medical and Pharmaceutical Merchandising) are presented and compared in the summary of table 2 .

The comparison of results at the stages of baseline assessment and final evaluation (Table 2) informs that the number of TG students reaching the creative level and the functional level of preparedness to professional activity increased by $15.5 \%$ and $11.1 \%$, respectively. At the same time, the number of students with a productive level and basic level reduced from $31.1 \%$ to $24.5 \%$ and from $20.0 \%$ to $0 \%$, respectively.

Table 2. Summarised results for the maturity of readiness of prospective MSNs to their professional activity at the stages of baseline assessment and final evaluation.

\begin{tabular}{|c|c|c|c|c|c|c|c|c|c|}
\hline \multirow{3}{*}{$\begin{array}{l}\text { Group category } \\
\text { and the stage of } \\
\text { control }\end{array}$} & \multicolumn{8}{|c|}{ Levels of readiness to professional meta-activity } & \multirow{3}{*}{ Mean } \\
\hline & \multicolumn{2}{|c|}{ Creative (5) } & \multicolumn{2}{|c|}{ Functional (4) } & \multicolumn{2}{|c|}{ Productive (3) } & \multicolumn{2}{|c|}{ Basic (2) } & \\
\hline & Stud. (n) & $\%$ & Stud. (n) & $\%$ & Stud. (n) & $\%$ & Stud. (n) & $\%$ & \\
\hline CG-baseline & 5 & 9.4 & 20 & 37.7 & 24 & 45.3 & 4 & 7.6 & 3.5 \\
\hline CG-final & 7 & 13.2 & 24 & 45.3 & 21 & 39.6 & 1 & 1.9 & 3.7 \\
\hline TG-baseline & 8 & 17.8 & 14 & 31.1 & 14 & 31.1 & 9 & 20.0 & 3.5 \\
\hline TG-final & 15 & 33.3 & 19 & 42.2 & 11 & 24.5 & 0 & 0 & 4.1 \\
\hline
\end{tabular}

Using the methods of mathematical statistics, we were able to demonstrate the probability and the significance of the resulting findings based on variance comparison to determine the F-test (Fisher's test). Comparative analysis of empirical F-test values in control groups and in experimental groups with predefined $F_{\text {test }}$ limits (from 1.8 to 1.4 ) has shown that $\mathrm{F}_{\text {emp }}-\mathrm{CG}$ with a value of 1.15 is beyond the aforementioned limits, while $F_{e m p}-T G$ with a value of 1.47 confirms the significance of the results obtained.

\section{Conclusions}

Therefore, using information/communication technology and computerised solutions, electronic educational resources, digital learning content, visualisation technologies, the Internet and active interpersonal collaboration within the electronic informational education environment creates virtual equivalents of intramural studies by continuous communication between all participants of the education process; this improves the achievement of readiness of prospective Masters of Science in Nursing to their professional activity. The results of this experimental study are supported by credible parameters, which have been verified using the methods of mathematical statistics. 


\section{References}

1. Makhnovska IR. Professional education of Masters of Science in Nursing within the framework of phased education: Ph.D. Thesis in Pedagogics, Speciality Code 13.00.04 (Ivan Franko State University of Zhytomyr). Zhytomyr. 2015; 26.

2. Makhnovska IR. The making and evolution of phased nursing education in Ukraine. The Bulletin of Zhytomyr State University. Speciality Line: Pedagogical Sciences. 2011; 60: 155.

3. Brazhnikov AY, Kamynina NN. Changes in nursing education in the European Union. The Nurse. 2007; 3: 35.

4. Klymenyuk VP, Sinelnikova FF. Modern nursing education in a setting of Ukraine's integration into the European educational domain. Head Nurse. 2007; 12: 11-14.

5. Dub NYe. The mechanisms for public governance of nursing reforms within the healthcare system of Ukraine: Synopsis of Ph.D. Thesis in Public Administration, Speciality Code 25.00 .02 (Lviv Regional Institute of Public Administration). Lviv. 2011; 20.

6. Voronenko YuV, Radysh Ya F. The historical aspects of emergence, establishment and development of legal regulation for medical operations in Ukraine. Ukrainian Medical Journal. 2007; 1(57): 47.

7. NCSBN (2015) Nursing Regulation Recommendations for Distance Education in Prelicensure Nursing Programs.Retrieved from http:// 15 DLC White Paper. Pdf

8. Palasyuk GB. Adopting Master's degree programs in Nursing: a step forward in reforming health sciences education in Austria. Medical Education. 2011; 3: 35-39.
9. Shehedyn MB. Nursing in Ukraine: a textbook. Ternopil, Ukrmedknyha Publishing. 2003: 280.

10. Kovalchuk LYa, Yashan OI, Yastremska SO, Konovalenko SO. Distance learning as a novel approach to phased nursing training. Nursing. 2010; 1: $5-6$.

11. Melnychuk IM, Yastremska SO. Current reality and perspectives of implementation of distance learning into the healthcare environment. Medical Education. 2016; 3: 17-20.

12. Martsenyuk VP, Rega NI, Gorodetsky VYe. Distance-based system of training as a modality to achieve educational qualifications of Bachelor and Master of Science in Nursing at Ivan Horbachevsky Ternopil State Medical University. Medical Informatics and Engineering. 2013; 2: 33-36.

13. Maximova VV, Yastremska SO. On problems of nursing development in Ukraine. Nursing. 2009; 3: 15-19.

14. Yastremska SO. Organization and implementation of distance-based training of Master's program students at the Research and Training Institute of Nursing of Ivan Horbachevsky Ternopil State Medical University. Education in Physics and Mathematics. 2017; 4(14): 132-137.

15. Yastremska SO. Pedagogical conditions for professional education of prospective Masters of Science in nursing in higher medical education institutions using the instruments of distance learning. Higher Education in Ukraine within the Context of Integration into the European Educational Domain. 2017; 21(78): 473-481. 